\title{
HIV health workers 'need better protection'
}

Paris. A group of French researchers, physicians, and healthcare workers have created an association to seek improved protection for healthcare workers from the risks of becoming contaminated with human immunodeficiency virus (HIV) through hospital accidents.

Fresh in their memories are the mid1980 s, when scientists and physicians failed to anticipate the danger of donated blood contaminated with HIV. Francis Cheilan, a vascular surgeon at the Passy Hospital near Paris, and president of the 'Union pour la Protection des Soignants et de leurs $\mathrm{Pa}$ tients'*, is keen that history should not repeat itself.

In particular, the association wants the health authorities to make it obligatory for hospitals to introduce precautions to reduce the risk of accidental contamination by HIV. Use of self-sheathing needles, for example, could reduce needleprick accidents by twothirds, says Cheilan. He also points out that such precautions would simultaneously protect healthcare workers from hepatitis B and $\mathrm{C}$ and other bloodborne diseases.

Similar precautions were also recommended by the ministry of health in a report released two years ago. But only a few hospitals have introduced safer procedures, says Cheilan. He claims that efforts by the health authorities to save centimes --a selfsheathing needle costs FFr3.0, whereas a standard one costs FFr0.8 - could cost lives, and accuses them of erecting a "wall of silence" for fear of creating panic.

Part of the problem, says Cheilan, is that the authorities are not convinced of the risks. Yet around 30 healthcare workers have already been confirmed as contracting HIV in work accidents in France, according to the association. It also claims that the real figure is probably closer to 300 , and will probably climb further as seropositive patients become more common.

In a bid to obtain better estimates, several Paris hospitals recently began testing simplified procedures for declaring work accidents. This was a response to the association's claim that existing procedures are so long and complicated that many healthcare workers instead prefer to cross their fingers.

The association believes that better social protection for contaminated healthcare workers is an essential step towards creating a climate in which the problem can be openly addressed. It is therefore demanding specific legislation allowing healthcare workers to claim adequate compensation.

At present, workers contaminated by HIV come under the legislation that covers general work accidents. This only entitles them to an invalidity pension, which is around one-third of salary, and many young healthcare workers are already only on the minimum wage.
The government introduced regulations last year linking the level of invalidity pension to the blood count of CD4 T lymphocytes (the cells depleted in AIDS). But it overlooked the fact that the legislation covering these regulations only allows invalidity pensions to be revised once every five years, irrespective of whether the worker gets sicker before the end of this period.

The association is urging the National Assembly to correct this contradiction immediately. Moreover, the decree formally stated that accidental HIV contamination comes under the law on work accidents. Cynically, say some, this means that healthcare workers are forbidden from seeking further compensation for hardship.

Pointing out that people contaminated by HIV through blood transfusion are auto- matically entitled to substantial compensation for "hardship caused", the association earlier this year wrote to Simone Veil, the health minister, demanding legislation to provide staff working in the front line with compensation more appropriate to the consequences of HIV infection.

Cheilan claims that the government and health authorities are "completely ignoring" the problem of accidental contamination of healthcare workers. In reply to a parliamentary question on the matter last December, Veil said the government had "a strong policy of information and training." But the association wants more done, and is considering taking a case to court to attract further attention.

Declan Butler

* UPSP, 10 Square Charles Baudelaire, 91450 Soisy sur-Seine, France.

\section{Greeks rue the fruits of success}

Athens. The Greek government is expected to approve this week the creation of a new unit to monitor the way in which public funds are spent on research, and to evaluate the performance of individual institutes.

But an overall shortage of money means that scientists and research groups receiving a good evaluation are unlikely to be rewarded with extra funding, while the government is not expected to accept the political price of closing institutes that perform badly.

Many Greek scientists have long

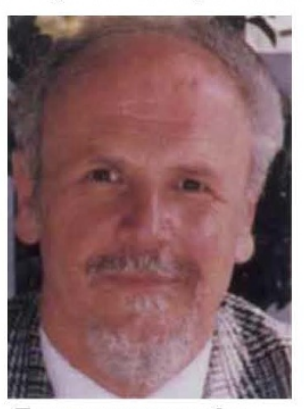

Economou: seeks a better reward. been concerned by the lack of a proper system of scientific evaluation of their work. Some research institutes have installed their own systems, but many have not.

In 1987, Eleftherios Economou, then the country's secretary general for research, introduced a complex formula for assessing government-funded research institutes and deciding how much money they should receive. The system took into account not only publication records, but also the amount of money raised from external sources - and a general judgement of scientific achievement made by the secretariat.

But the system has not been used in the $1990 \mathrm{~s}$. The real value of government funding has dropped steadily, and it now barely covers salaries and basic running costs. Research institutes that are successful in attracting outside funding end up finding their public funds reduced, as the government feels they are less in need of public support.
The Foundation for Research and Technology Hellas (FORTH), for example, which runs seven research institutes, four of them in Crete, has seen its government funding fall from Drs 1,176 million (US\$4.6 million) in 1990 to Drs614 million in 1993.

Economou is now FORTH's director, and criticizes the government's policy, as he feels it fails to provide any long-term security for his research centre, the second largest in Greece. He is seeking a more solid basis of government support, based on his centre's scientific track-record.

Many scientists feel that the judgement of the general secretariat now carries more weight than was originally intended by Economou, and that a close working relationship between the institutes and the secretariat has become more important than the scientific value of the institute's research.

It is in response to these concerns that the new unit is being established. Nicos Christodoulakis, the secretary general, has called a meeting on 20 May of institute directors to discuss the mechanisms by which it will assess institutes.

But whatever the new assessment criteria, it is clear that reward for good performance will not be financial. Christodoulakis says that simply publishing the results of the assessment exercise should be sufficient to stimulate researchers to improve their own output by encouraging greater competition.

Many Greek scientists welcome the prospects of stronger central evaluation. Socrates Tzartos, head of biochemistry at the Hellenic Pasteur Institute in Athens, for example, accepts that publishing the results of the evaluation may be effective. But Tzartos and others are sceptical about the government's ability to put its plans into practice.

Allson Abbott 